\title{
Visió Comparatista sobre la Poesia Visual de Joan Brossa i el Disseny Gràfic
}

\author{
Mireia Vidal-ConTE \\ "el poeta aparece como un 'creativo' palabra \\ con la que se designa al que compone los slogans \\ en las empresas publicitarias-.." \\ "jo crec que la poesia visual no és dibuix \\ ni pintura, és un servei a la comunicació»
}

(JOAN BROSSA, poeta)

"el acercamiento del diseño gráfico a las corrientes de las nuevas tendencias formales (...) se produjo al coincidir la naturaleza del diseño comercial con una de las prerrogativas del nuevo arte: pretender lo efímero como horizonte temporal»

(ENRIC SATUÉ, publicista)

\section{INTRODUCCIÓ}

¿Per què quan vaig tenir a les meves mans el llibre de disseny gràfic Logos made in spain, de Màrius Sala, i el vaig fullejar, vaig pensar automàticament en l'obra visual de Joan Brossa?'

¿Per què em va semblar tenir claríssim que disseny gràfic (sobretot si ens referim a la vessant de creació de marques i/o logotips) i poesia visual tenen molt a veure?

¿Quins elements comparteixen aquestes dues grans àrees, i quins altres les diferencien? $\mathrm{O}$ el que és el mateix: ¿què pren la poesia visual del disseny gràfic i què prèn el disseny gràfic de la poesia visual?

Evidentment, aquesta feina podia haber estat abordada prenent com a referents altres poetes visuals, així que l'elecció de Brossa ha estat purament una

1 Sempre que em refereixo a logotip o marca, vull indicar com a marca el nom que utilitza el comerciant per distingir els seus productes; i logotip, la imatge amb la qual «vesteix» aquesta marca. Així parlarem d' «El Corte Inglés», com a marca, i de logotip quan ens referim al triangle verd amb aquesta marca en blanc a dins. De tota manera, durant aquest estudi no considero de rellevància quan considerem l'un o l'altre, ja que en l'argot s'utilitzen sovint ambdós mots per definir el de logotip (donat que a vegades coincideixen el nom, la marca i el logotip a la vegada). 
qüestió de proximitat a la seva obra, i d'interès propi com a home provinent de la branca de comunicació, i com a poeta, artista polifacètic...

El treball de recerca i de reflexió l'he centrat en les preguntes anteriorment esmentades, més que no pas en l'anàlisi de l'obra de Brossa específicament i de les metodologies del disseny gràfic actual. M'interessen conceptes més genèrics com són: objectius de la recepció d'ambdós missatges, elecció del tipus de llenguatge, tipus de missatge, motius de creació, importància dels elements, i trobar - com he dit- elements d'unió entre les dues grans àrees a partir del convenciment que molts poemes visuals de Brossa (i em remeto principalment durant tot l'estudi, als poemes en què pràcticament Brossa no utilitza els mots, els quals pràcticament estan configurats d'imatges o motius gràfics) poden arribar a produir sensacions bessones a l'efecte que pot provocar una imatge producte del disseny gràfic. Molts poemes de Brossa, sota el meu punt de vista, podrien ser perfectament producte del disseny gràfic (si en comptes del títol, portessin imprès el nom d'una marca comercial). I també m'he trobat amb cassos invertits: hi ha vegades que un logotip ens remet a un pensament no merament comercial... hi pot haver conceptes poètics... només hi hauríem de posar un títol adequat.

Així doncs, parteixo de mi mateixa, sobretot de la meva bicefâlia en publicitat i crítica literaria.

Breu biografia de Brossa

D'origen menestral, Brossa va néixer el 19 de gener de 1919 a Barcelona, al barri de Sant Gervasi. Als disset anys serví al front de Lleida integrat al servei de l'exèrcit republicà, època en la qual va escriure un dels primers treballs literaris, de caràcter militant (tret que retrobem en bona part de la seva obra). Torna a fer el soldat a Salamanca, on s'interessa per Freud i la psicologia, i quan torma a Barcelona escriu textos en vers lliure.

En la posguerra treballà com a gravador (fet que, pel que veurem després, podria també haver determinat els seus coneixements sobre grafisme) i venia llibres prohibits.

De seguida entrà en contacte amb alguns dels artistes més significatius de l'avantguarda catalana com J. V. Foix i Joan Miró. A través del primer s'interessà per l'aspecte formal dels textos. Més endavant coneixerà Antoni Tàpies, amb qui col-laborarà.

Al setembre de 1948 és membre activíssim de la revista «Dau al Set»i des de llavors vincularà la seva obra amb les arts plàstiques.

Fins al 1970, any en el qual es publicà Poesia Rasa, visqué en l'obscuritat i el refús. A partir d'aquesta època comencen a tenir més ressò les seves obres: Poesia escènica (1974), Sonets de Caruixa (1949), Dragolí (1950), Em va fer Joan Brossa (1952), Poemes civils (1961), El saltamartí (1969), Poemes de seny $i$ de cabell (1977), Rua de llibres (1980), Ball de sang (1982), Càntir de càntics (1972), La barba del cranc (1974), Poemes visuals (1975), Antologia de poemes de revolta (1979), Vint-i-set sextines $i$ un sonet (1981), Accions Musicals (1975), Sextines 76 (1977). 
Brossa també va ser conegut per la seva activitat com il-lustrador, a partir de poemes visuals que compongué per a cartells (és a dir, a escala professional no dubta a realitzar feines pròpies d'un dissenyador gràfic o d'un dibuixant; en aquest cas: coneix el seu llenguatge $i$ les seves intencions).

L'any 1954 s'estrenà a Barcelona la seva primera peça teatral, Farsa com si els espectadors miressin l'escenari a vista d'ocell.

L'any 1968 col-laborà amb músics, i estrenà el Concert irregular. També va intervenir en projectes cinematogràfics. poeta.

Així doncs, un artista polifacètic, tot i que ell sempre es va definir com a

En la seva formació literària van ocupar una posició destacable les lectures de Verdaguer, Guimerà, Ignasi Iglésies, lectures menestrals de l'època, i en quant a referents culturals, Salvat-Papasseit, Wagner, Frègoli, Rimbaud, entre d'altres.

Ocuparen un lloc important els surrealistes, ell mateix es definia com a «neosurrealista».

Contextualització de l'obra brossiana —anys 50: revolució dels mass media-

Als anys 50, els publicistes comencen a incorporar en el dibuix comercial les modes i les maneres de l'art conteporani, sobretot per donar un més gran valor expressiu i assolir una més preuada originalitat de l'anunci, per tal d'aconseguir destacar. Són disciplines connectades artísticament per molts motius: sovint hi ha un traspàs de professionals d'un cantó a un altre, el dissenyador buscant l'oasi artístic per poder canalitzar aquesta vessant, i l'artista per trobar una via propera a la seva concepció professional però que li aporti una remuneració més «estable».

En aquests mateixos anys ens trobem als inicis del consumisme: el dibuixant publicitari haurà d'estar disposat a captar i reflectir totes les novetats, donat que el temps i les modes, amb canvis accelerats, poden jugar en contra dels seus treballs (dinàmica que també es produeix als nostres dies): és a dir, el publicista es mou en unes "velocitats econòmiques» que no preocupen de cap manera l'artista, si bé aquest també les viu perquè el pintor, el poeta, no és aliè a aquesta dinàmica. S'hi troba $i$ en surt influït en certa manera.

Dins d'aquest moviment social que esdevé durant aquests anys, el comunicador visual ha de conèixer exactament a qui dirigeix les seves realitzacions:

"L'arquitecte ha de conèixer els costums, el gènere de vida dels éssers humans que circularan per la seva construcció (...) però el tècnic publicitari opera amb una matèria molt més extensa i profunda: sobre els milers o milions de persones que llegiran el diari, escoltaran la ràdio o passaran pels carrers on existeixen els anuncis (...) i existeix l'obligació d' una profunditat que no exigeix a l'arquitecte, donat que necessita conèixer les constants físiques dels re- 
ceptors de la seva obra però, ademés, la seva psicologia, i no només en el terreny mecanicista $i$ somàtic de la psicologia clàssica, sinó en el profund $i$ immens camp de l'inconscient" (Alexandre Cirici i Pellicer)

(quina casualitat que una de les lectures més importants de Brossa - tal i com hem comentat a la seva biografia- foren les obres de Freud...!)

El poeta té aquesta necessitat de definició del receptor? Diríem que no tan acurada, tot i que Brossa sabia que la seva obra s'emmarcava en una societat caracteritzada pel fenòmen dels mitjans de masses, $i$ aquest fet feia que el seu receptor -que en formava part, evidentment- tingués una formació audiovisual molt important. Aquest fet, barrejat amb la recerca d'un llenguatge que l'apropés a la «realitat essencial» que ell pretenia, el va portar cap al llenguatge visual (en parlarem posteriorment). El gran públic, és un ens àvid d'imatges i exigeix cada vegada més una major qualitat temàtica i tècnica... i Brossa sap que és aquest públic el que possiblement pot passar a ser un lector de les seves obres... amb això, però, no vull dir que Brossa escrivís pensant específicament per tal que els lectors el compressin, o bé utilitzant el llenguatge que aquests li requerien... no ben bé, sobretot coneixent una mica la biografia del personatge, mai donat a «claudicar» per motius comercials ni polítics de cap tipus, però és evident que la seva vida social i, per tant el seu procés creatiu, s'emmarquen en aquest context i l'indueixen a trobar un nou llenguatge més «expressiu» (a més dels seus dubtes envers el llenguatge literari heretat).

«El fet d' haver-hi la reproducció mecànica de les imatges significa establir un sistema de codis visuals aptes per la majoria de la gent integrada a un estament social amb possibilitats d'educació $i$ d'accés als mitjans de cultura i comunicació» (Ricard Huerta).

... i això Brossa ho sap, i ho viu, i ho capta en el seu procés creatiu de gestació...

Es troba dins una nova cultura de la imatge, que influeix directament la seva obra, i en treu profit.

"Si les lletres havien significat un element al servei de les idees mentre va durar l'inici de la cultura del llibre imprès, a partir del naixement de la fotografia i de la premsa il.lustrada les lletres comencen a adquirir molta més importància com a element plàstic, ja que hauran de complementar l'entorn de les imatges de pàgina que han estat transformades per les fotografies $i$ les il-lustracions" (R. Huerta).

Les lletres, doncs, haurem de considerar-les com a exponent de la cultura visual apte per la feina del poeta visual i apte, a la vegada, per la feina del dissenyador gràfic.

La Poesia brossiana-el llenguatge $\rightarrow$ primeres comparacions amb el disseny gräfic-poesia visual, transició cap a la imatge- 
Com a primera consideració, la poesia brossiana és prou allunyada de l'actitud lírica convencional que caracteritza la major part dels poetes de la seva generació. Pot ser qualificada d'avantguardista, pel to antiacademicista, i per l'ús d'algunes tècniques, com el rebuig de la discursivitat, els mots en llibertat, etc.

Brossa no es planteja la relació entre autor i lector en termes ordinaris: la lectura és una provocació, un interrogant sobre la realitat adreçat al lector, però també una sol-licitud de col-laboració.

D'aquesta afirmació ens quedaríem bàsicament amb dos conceptes pel que tenen de relació amb el nostre tema de debat: PROVOCACIÓ i SOL.LICITUD DE COL.LABORACIÓ. Dos conceptes que també són intencionadament buscats pel dissenyador gràfic amb la realització de la seva feina. La provocació, per aconseguir l'efecte de notorietat en el moment de recepció del disseny per part del públic: ha de ser quelcom prou inquietant, prou «diferent» per aconseguir destacar entre tota la selva mediàtica a la qual està exposat el receptor; i la sol-licitud de col-laboració, per tal d'establir la complicitat necessària -i mnemotècnica! - amb el consumidor (receptor etern de la feina del dissenyador gràfic), per tal de fer del nou logotip una imatge ben aposentada dins el seu univers mediàtic.

Brossa, doncs, també intenta sempre aconseguir la participació del lector, perquè la pròpia execució de l'obra n'és un element integrant, cabdal i tot, de la comprensió total.

Aquí és on el disseny gràfic no disposa de tanta llibertat d'actuació amb l'element «atzar». No pot deixar en mans del receptor la interpretació de l'element; els seus objectius són molt concrets i ha d'aconseguir que siguin entesos sense confusió ni dobles interpretacions: li paguen per això (diferència que ja presumim bàsica entre l'artista - animal lliure, en principi: Brossa com a mínim sembla que lluitava per a ser-ho- i el dissenyador - mercenari de la comunicació-).

Per Brossa, «La imatge poètica només és vàlida quan estableix un lligam profund entre el símbol i la veritat psíquica».

I la imatge gràfica, creada pel disseny gràfic: el logotip? ¿Podríem dir que «la imatge gràfica només és vàlida quan estableix un lligam profund entre el PRODUCTE i la veritat psíquica»? Intuïm que sí. El que busca el dissenyador amb la seva feina són diversos aspectes que tractarem més endavant -quan parlem més específicament del disseny gràfic-, però entre ells segur que hi trobem aquesta relació entre el producte que representen i el món psicològic del públic a qui va dirigida la realització (en definitiva: comunicació). S'ha de produir aquesta connexió, per l'èxit del disseny final.

El centre cabdal de la poesia de Brossa són els mots. I l'interessen pel que tenen d'objectes en ells mateixos, autosuficients; i per la utilitat a l'hora de presentar objectes que tenen, al seu entorn, una possibilitat de representació visual. És evident, doncs, que existeix una preocupació en Brossa per l'eficàcia del llenguatge escrit com a mitjà de comunicació.

Entre els anys 1960 i el 1975, Brossa treballa cada cop més en termes d'essencialitat o conceptualització. La seva recerca se centra en l'essència de les coses; 
el poeta es preocupa pel poder representatiu de les paraules i comença a reflexionar per tractar de captar la idea d'una manera sintètica... Brossa està viatjant ja cap a la poesia visual, considerada com aquella composició poètica que substitueix els ingredients tradicionals del poema (ritme, metre, estrofa i sintaxi) per altres elements extrets dels repertoris tipogràfics, del gravat, del dibuix, de la foto i dels codis d'informació no lingüística, sovint inserits en la vida quotidiana. Gloria Bordons ens assenyala que «de fet, molts poemes visuals són semblants a missatges publicitaris. El que els fa diferents és la seva càrrega conceptual»...

«Las Vanguardias históricas se propusieron asumir el discurso de la publicidad como el de máxima efectividad y capacidad de síntesis» (Sonia Mattalía, Universitat de València).

«el concret-visualisme és la fusió de les retòriques pròpies del gènere literari poètic i de les arts plàstiques, sense oblidar tampoc la influència dels discursos publicitaris i el disseny industrial» (Fernández Serrato).

Els elements plàstics del poema poden combinar-se amb lletres, paraules. El pas cap a aquest tipus de poesia, representa una reacció a la poesia tradicional i es situa a la cruillla de la literatura $i$ les arts plàstiques.

I comença a centrar cada cop més el seu interès en la comunicació (igual que en les produccions sortides dels cervells dels dissenyadors gràfics). Les regles que imposa al lector són les d'un joc que porta a terme amb paraules, lletres o, simplement, amb les idees: la seva poesia pren cada cop més una vessant més lúdica i participativa.

Aquesta complicitat per part del receptor aconsegueix produir-se bàsicament pels factors de l'educació, la memòria i la percepció, així com d'altres aspectes de la psicologia. En el cas de les lletres, el component social de l'educació influirà d'una manera decisiva en la captació d'un llenguatge visual (tant pel que fa a la missió de Brossa, com pel que fa als objectius que busca el dissenyador gràfic. És necessari - sobretot pel segon-compartir el mateix codi d'enteniment).

En aquests moments, Brossa mira d'allunyar-se del món literari per un interès també d'adaptació a la modernitat, tot i que és oportú puntualitzar que continuarà treballant formes mètriques noves.

«el llenguatge adopta un sentit genèric que comprèn els diferents mitjans d'expressió que l'ésser humà ha desenvolupat ilo ha inventat durant el transcurs de la història, sempre amb relació a unes necessitats determinades. Aquesta visió està molt vinculada a l'activitat creadora de Joan Brossa (...): l'ús dels diferents mitjans d'expressió a l'abast de l'ésser humà (...) i la concepció de la poesia com una activitat que abasta la totalitat expressiva de l'ésser humà: els mitjans d'expressió (la imatge, el cinema, la televisió, el videoclip, etc.), ens diu el poeta, són eines interessants» (Isidre Vallès).

I, segons Brossa,

«per què el poeta ha d'estar sempre presoner del llibre? (...) No necessàriament hem d'escriure versos (...) Un creador autèntic ha d'assajar sempre llenguatges diferents". 
(que l'hi diguin a un publicista..., per a qui la combinació de tots els recursos audiovisuals són vàlids per la consecució dels objectius determinats -d'acord: no en el cas de la realització de logos; sí però en l'establiment del llenguatge publicitari global-).

«La capacitat representativa del mot en designar un objecte $i$ suggerir-ne una imatge conceptual podria ser el primer pas en el cami que condueix cap a la poesia visual com a resultat del deliberat esforç brossià per obtenir la identitat total entre els mots $i$ les coses.

L'equivalència que estableix la ment entre imatge conceptual i iconicovisual és un punt de trobada dels dos tipus de representació que podia haver facilitat la irrupció iconogràfica» (Isidre Vallès).

Una breu puntualització respecte als codis no-linguiístics que utilitza Brossa, més relacionats amb els signes, el dibuix i el llenguatge publicitari. Esdevé un llenguatge sense fronteres, supranacional: parlem de la «poesia semiòtica» (segons Bordons) plena de signes, ja existents o inventats per l'autor, que de vegades són simples indicis per al lector.

Com a conclusió, aquesta recerca que fa Brossa, cap a un llenguatge nou, perquè el que existeix no el satisfà: per què no el convenç? Per aconseguir què? expressar el que sigui a qui sigui? Estem, doncs, davant d'una recerca de noves solucions per comunicar millor... és la recera constant i diària del publicista!

Aquí, però, Brossa va caure en un risc que el dissenyador no podria mai permetre's: el fet de la novetat; la manca de tradició en el nou llenguatge. El producte del disseny gràfic ha de garantir-se al cent per cent la total intel-ligibilitat: si no funciona, haurà suposat un fracàs professional... de cara a l'artista, potser més prestigi i més reconeixement com a treball d'experimentació.

Importància $i$ sentit de les lletres -poesia i disseny gràfic-

Algunes de les puntualitzacions que R. Huerta fa sobre les possibilitats comunicatives de les lletres que crec que ens ajuden a entendre la utilització d'aquests símbols tant en el cas de la poesia de Brossa, com en la conceptualització del missatge del dissenyador gràfic:

«(..) 2. Les lletres ens poden transmetre, de manera idònia, una època $i$ una cultura determinades, amb la qual cosa es converteixen en signes identificables immediatament.

3. En el gest de cada símbol trobarem un gran nombre de característiques $i$ referències directes.

4. Les lletres ocupen sovint el camp topogràfic que la fotografia i el dibuix no completen amb els seus respectius missatges.

5. La lletra pot arribar a transformar $i$ anul.lar en molts casos el paper de la imatge figurativa i/o no figurativa. 
6. En el cas especific de la publicitat, el text s' erigeix en atribut gräfic necessari per a servir d'enllaç entre el producte ofert i el públic que l'haurà d' $i$ dentificar visualment i oralment. (...)"

El traç de la lletra i l'ornamentació dels texts aporten una ambientació del missatge que passa de ser una informació només verbal a desxifrar tot un conjunt de continguts molt més específics del tema representat. Caldrà veure quins són aquests continguts (artístics, per la banda de la poesia visual; i comercials per la banda del disseny), i estudiar mitjançant quina lletra es poden comunicar millor.

«Si el llenguatge -els signes verbals—ens són indispensables per a definir el món, l'expressió escrita - dibuixada-d'aquest llenguatge ens condiciona visualment en tots els camps de la recepció i el comportament visual, ja que els codis establerts han transformat la realitat que representen, $i$ ens la canvien per poder-la personalitzar amb un major criteri individual» (R. Huerta).

Brossa sabia que una lletra era sobretot un grafisme $i$ una imatge. Un signe aïllat i individual amb un aspecte plàstic suggeridor d'àmplies possibilitats de desenvolupament gràfic (fet que enllaça amb la utilització de la lletra al disseny) i de sorpresa: el fet sorprenent que també perseguiran Brossa i dissenyador anònim.

«Amb el grafisme de cadascuna de les lletres podrien simbolitzar-se perfectament els fets, les figures, els elements, les passions, i tota una àmplia gamma d'idees $i$ successos que posteriorment enllacem amb la pròpia i exacta interpretació personal» (R. Huerta).

Ho coneixia Brossa i ho coneixen tots els professionals del disseny gràfic $i$ queda prou exemplificat en l'anex d'exemples, l'experiment seria clar: quina sensació tenim al veure un logotip o un altre -inclús sense saber a quina empresa comercial fa referència - Al publicista l'interessa moltíssim què s'amaga a nivell de concepció psicològica darrera del format d'un tipus de lletra, ja que la memòria visual actua molt eficaçment per a accedir al desig de posseir el producte en qüestió. Hi ha tota una sèrie de característiques inherents, per exemple, en aquest tipus de lletra que ara utilitzo, força diferents d'aquest altre tipus de lletra. Doncs aquest efecte és el que s'aplica al producte del disseny gràfic, evidentment, no per només un fet estètic (que també existeix, no hi ha dubte) sinó buscant que una paraula, escrita juntament amb uns colors, provoqui una sèrie de connotacions molt relacionades amb la compra final del producte que representen.

Estem buscant el vehicle més adequat per transmetre una sèrie d'idees: artístiques l'un, comercials l'altre, però es serveixen de les mateixes eines. És com viatjar per plaer, o viatjar per feina... ${ }^{2}$

Brossa parlava de comunicació, de publicitat (o disseny gràfic) i de poesia -només cal llegir-lo-

2 Brossa va fer un poema visual «TREN», que al catàleg de Joan Brossa i Nicanor Parra (bibliografia) el consideren un logotip $(i !)$. «un tren con dos máquinas en cabecera y cola, para ser pin- 
"El poeta contemporani disposa d' una paleta amb molts colors. La qüestió és fer-ne bon ús i portar a fons totes les possibilitats. Des de la poesia retòrica fins als experiments visuals, videoclips...".

(Parlant del procés creatiu): «primer, la recepció d' estímuls, paraules pel carrer; llegir el diari; qualsevol esdeveniment és bo per disparar la imaginació. Cal estar sempre obert (...) El més imprevist és a tocar de la realitat més quotidiana. Es tracta de 'saber-ho veure'".

(amb aquestes mateixes paraules són amb les que responen els professors de Comunicació Audiovisual quan algú pregunta pels processos creatius de la idea publicitària: «heu de ser curiosos... observadors... us ha d'interesssar tot!»).

«Abans que una obra faci funcionar el cervell, ha de produir un cop de puny. Paf!». "La poesia cada dia pot ésser una cosa diferent. (...) Potser et diria que és l'organització de la sorpresa (...) és agafar l'onda d'un estat d'ànim i projectar-se. $L$ 'art és un assaig de correspondència entre creador i espectador. (...) La poesia existeix sempre i el poeta només fa petits vehicles on la condensa».

«Vaig començar a fer poesia visual com una necessitat de travessar el límit d'un llenguatge $i$ assolir un terreny menys codificat, més universal. Jo no menyspreu per res el codi literari, però passa que les paraules es gasten. Es tracta d' establir un lligam nou entre el camp visual i el semàntic».

"M' han mogut a fer poesia visual, precisament, els mitjans de la nostra societat que porten en ells mateixos impactes d' imatges i colors».

"Si quan el poeta parla d" un moli de vent el pintor ha de dibuixar-lo, pleguem. Això és limitar la imaginació del lector".

"-Com faries el comentari d' un poema visual, tu?

-És important que hi hagi un interrogant davant el poema. (...) El mires i el copses, o no.»

(Aquí una breu acotació: l'interrogant pot existir en una campanya publicitària o, més específicament pel que ens tracta, en un logotip. Però és un interrogant que només podrà durar uns segons... - si és que existeix - perquè el receptor ha de saber-ne la solució per aconseguir l'objectiu del disseny gràfic; del producte. En el signe plàstic l'atribució de contingut no té caràcter de necessitat... i no així en el signe producte del disseny gràfic).

«M'agradaria eprofitar una sèrie de llenguatges visuals que la societat de consum et posa a l'abast. És un repte perquè avui fer un sonet resulta fàcil».

«La poesia no és un art exclusiu de la literatura».

(només li faltava continuar una miqueta la frase):

tado a lo largo del TAV español, diseñado de tal manera que produce la sensación de que el tren se mueve simultàneamente en los dos sentidos.»

Així doncs ja tenim la certesa, la constatació, la prova irrefutable, que Brossa entenia i compartia l'expressivitat publicitaria, fins al punt d'exercir ell mateix com a dissenyador. 
"La poesia no és un art exclusiu de la literatura; el trobem, per exemple, en les pròpies realitzacions del disseny gràfic »³.

Llenguatge Publicitari - disseny gràficversus Llenguatge Poètic Comunicació i Poesia-

"La idea, en publicitat, ha de tenir la connexió idònia entre fons $i$ forma, fonament $i$ exposició, contingut $i$ continent. Quan parlem de fons, parlem de la idea en el sentit apel-latiu, la línea argumental, les raons $i$ els motius que impulsaran a la persuassió. La forma, és tot alló extern i apreciable, el suport estètic que s'argumenta a base d' imatges o paraules, amb un missatge gràfic que necessitarà disposar d'un màxim de poder de captació, estimulant els desigs mitjançant els sentits. Les dues parts s' hauran de complementar, la part externa haurà de ser conseqüència del contingut específic. El fons s' ha de convertir en forma, per poder assimilar així —amb recursos psicològics-la intensitat necessària de captació, que òbviament es transforma en necessitat d'adquirir el producte» (Ricard Huerta) ${ }^{4}$.

Per un moment, podríem fer l'experiment de canviar l'inici i, en comptes de «en publicitat», podriem dir «en poesia»: crec que la primera frase quedaria absolutament igual. És necessària aquesta connexió entre fons i forma perquè el receptor arribi a entendre el que el poeta està intentant transmetre. En quant a la segona frase, em fa dubtar la paraula "persuasió». És evident que el poeta no pretén persuadir a ningú... o sí? Potser no de cara a la realització d'una acció concreta (en el cas de la publicitat, la compra final), però sí com a «seducció» artística. Sí que crec que Brossa, en molts dels seus poemes de poesia visual en els quals només hi trobem una lletra i un grafisme, per exemple, no pretén que passem pàgina $i$ ja està (total... «només una lletra i un dibuix!»), sinó que vol que ens aturem, que somriguem... Un dels poemes brossians: «només» hi veiem, al centre del full, la paraula «Tos»: no hi apareix cap imatge gràfica, però és cert que Brossa aconsegueix una mena de persuassió/ seducció. Cadascú de nosaltres tindrà una «tos» al cap... i ens aturarem... i viurem aquella «tos» durant uns segons... i potser el que passarem més ràpidament serà aquell poema de tres pàgines que no s'acaba mai... (difícil, precisament, en Brossa).

Bé, continuem amb la frase... pel que fa a la idea que representa el «fons», en el cas del disseny gràfic és quelcom que el comunicador ha de tenir molt clar i que ha de transmetre amb aquesta claredat al receptor. No ens passa així amb el món poètic: hi ha poemes de Joan Brossa, que només pertanyen al seu món. I que, llavors, es produeix aquest decalage entre «el que et vull dir i el que tu entens». Això no s'ho pot permetre mai un dissenyador gràfic. Ha d'estar absolutament segur que el resultat final arribarà a bon port adequadament i, sobretot, intel-ligiblement.

\footnotetext{
${ }^{3}$ La negreta ês meva.

4 La negreta és meva.
} 
Quant a la definició de «forma», no tindria res a dir. Ambdues disciplines busquen la correspondència amb el fons i cerquen (per diferents raons, això sí, l'una més dirigida al gaudi o a la reflexió, i l'altre més dirigida al desig de possessió del producte o d'identificació amb ell) l'estimulació dels sentits del receptor.

Evidentment, en la poesia no hi ha cap necessitat d'adquirir res... (o sí?... sí, d'alguna manera hi ha aquesta voluntad de seduir a l'auditori... el poeta no fa un poema i ja està, busca, interiorment, la fidelitat del receptor... i en fa més: per una necessitat pròpia i per una necessitat de continuïtat) i sí en l'objectiu del producte gràfic (el qual existeix per i per a l'acte final de compra de l'element representat en qüestió).

La importància de la configuració del missatge en quant al moment de la seva recepció és important per Brossa, però també (i molt!) pels objectius que persegueix el llenguatge publicitari. Pel que fa al lector de la proposta visual artística, Brossa coneix quina és aquesta cultura i quins poden ser els mecanismes decodificadors que poden actuar en la recepció del missatge que proposa. Ho sap igual que ho té que saber un dissenyador gràfic, el qual intenta provocar un recurs memorístic en el receptor (tinguem en compte que la forma d'una lletra $-\mathrm{o} / \mathrm{i}$ un dibuix -, la tenim molt més assimilada que qualsevol altre signe o símbol.) gueixen?

¿Com es produeix aquesta decodificació que ambdós professionals perse-

Tot comença en la decodificació a partir del llenguatge visual, el qual no ha estat creat amb la necessitat de ser transportat a matèria fonètica, com deia el lingüista danès Hjelmslev, tot $\mathrm{i}$ que immediatament les traduïm als sons dirigits a l'oïda, això gràcies a l'hàbit de llegir i escriure. I aquest procés és el que, segurament d'una manera inconscient, coneixen els professionals d'ambdues àrees, segurament de manera inconscient. raules.

Un altre pas comú per la decodificació, per exemple, el context de les pa-

Del Disseny Gràfic

$i$ dels dissenyadors

—alguns apunts que no voldria obviar-

Els dissenys mai són (o no ho haurien de ser) la finalitat del dissenyador (una altra gran diferència que sumem a les ja esmentades durant l'estudi, fins ara), exeptuant l'il.lustrador. Són el mitjà per aconseguir la producció definitiva que tindrà com a principal objectiu la comunicació (generalment, de la possibilitat d'adquisició d'un producte «X»).

Les etapes del disseny són moltes $i$, en totes elles, hi intervé un element que farà que moltes vegades el criteri del dissenyador -del professional al qual han contractat per solventar un problema - se'n vagi en orris: el client.

La producció final del dissenyador anirà acompanyada probablement d'informes de tot tipus que justificaran la feina realitzada, a més de les corresponents adequacions als diferents mitjans de comunicació. 
Des del punt de vista d'un publicista i professor, Bruno Munari, la comunicació visual:

"és en alguns cassos un mitjà imprescindible per a passar informacions d'un emissor a un receptor, però la condició essencial pel seu funcionament és l'exactitud de les informacions, l'objectivitat dels senyals, la codificació unitària, l'absència de falses interpretacions."

«Exactitud de les informacions», no pas en poesia visual, on a vegades el lector pot entendre un missatge gens relacionat amb el que volia transmetre l'autor... «l'objectivitat dels senyals», bé, dependrà de l'artista, i del codi que escull...

«l'absència de falses interpretacions», a vegades no s'acompleix en la poesia visual.

En aquesta definició, doncs, no coincidirien les dues àreas. El mateix Munari reconeixerà més endavant que:

«existeixen moltíssims casos (...) en els quals la comunicació visual es produeix d' una manera confusa, bé sigui perquè comporta d'altres informacions innecessàries, bé perquè la formulació visual és 'bruta', bé perquè no s' ha establert ni controlat adequadament el codi».

Diria que és l'última apreciació la més adequada als problemes d'intel-ligibilitat que es produeixen en la poesia visual.

Enllaçant amb la passió de Brossa respecte a allò quotidià, com a màxim representant de la realitat viscuda (la més propera a l'essencialitat, segons Brossa, com ja hem vist), citaria unes paraules del dissenyador industrial André Ricard:

«És precís que el disseny més discret d' allò realment útil i quotidià, aquell que perdura més enllà de les modes, sigui reconegut com la millor resposta a la bogeria consumista a la qual ens aboquen les coses que es regeixen per les modes. És aquest el missatge directe i obvi que l'usuari és capaç d'entendre sense necessitat de cenacles paternalistes que l'orientin".

En les reflexions que planteja aquest mestre del disseny industrial, hi trobem un llenguatge molt proper a l'essència esmentada que cercava Brossa. Aquell, però, l'aplica a la recerca de l'objecte pur o, com ell l'anomena, «l'objecte-objecte».

Crec que, en essència, buscaven el mateix, un missatge: la utilitat màxima de la comunicació per expressar l'un, art poètic; l'altre, art utilitari objectual. Trobo que Ricard parla de la seva problemàtica des d'un punt de vista paral.lel si més no al que preocupava Brossa.

«los objetos-útiles aparecen como simples fenómenos formales cuya morfología se aprovecha para expresar un determinado mensaje; de tal modo, que se inserten en el mundo simbólico que cada sociedad genera. Todo lo que vemos puede ser vehículo de significados. Existe un verdadero lenguaje de las formas, del mismo modo que existe el de los signos. Como todo lenguaje, también éste 
se establece en torno a un código de convenciones establecidas, propias de determinado contexto socio-cultural. Aunque este lenguaje posee un territorio propio, también puede ser compartido por más de un grupo social o cultural. Es mediante este lenguaje connotativo de las cosas, incluso las más útiles y elementales, nos "hablan», actualmente, de algo más que de su propia función.

(...) Así, la creciente importancia que adquiere este mensaje, va reforzando, a su vez, el valor significativo de las cosas, hasta el extremo de que se llega a «utilizar» un objeto-útil más por su valor significativo que por el servicio real que ofrece».

(enllaçaríem, també, amb la problemàtica de les «paraules cansades»).

Si definim les funcions principals que les marques comercials i els logotips configuren respecte a allò que representen, comprovarem quines són les diferències de connotació respecte l'art:

- identifiquen d'un producte,

- el diferencien dels altres,

- comuniquen informació sobre l'origen, el valor la qualitat, afegeixen valor i aporten confiança

- volen representar potencialment quelcom valuós

- constitueixen propietats legals importants

Bé: la identitat única d'un poema, no implica la seva identificació? (tot i que no és mai missió de l'artista).

Encara que no per la voluntat del poeta, un poema ¿no suposa - per únicla diferència amb els altres? Se suposa que el que pretén l'artista amb la seva obra és aportar una originalitat i una diferenciació respecte els demés col-legues...i els demés poemes...

I segons J. Murphy i M. Rowe:

«muchos diseñadores de marcas y logotipos gustan de imaginar que están en un proceso creativo puramente abstracto o cerebral: se sientan provistos de una hoja en blanco y un rotulador, y el diseño perfecto, de algún modo, aparecerá en la punta del rotulador, sobre la hoja».

(generalment són els processos que donen com a resultat un logotip que mai aprova el client i una obra d'art que podria ser signada per... Brossa?)

\section{CONCLUSIONS}

- La gran diferència entre les manifestacions artístiques més convencionals (pintura, escultura, arquitectura, etc.) i allò que coneixem com a arts aplicades - disseny gràfic - rau en el fet que els productes de la cultura de masses són efímers, almenys en molt més alt grau. Per tant, l'esforç de realització que suposa el treball d'un dissenyador gràfic rau en aquesta transitorietat que s'ha de solventar amb la força memorística que presen- 
ti el seu treball. Aquest fet és inexistent en la feina del poeta, treball del qual és consultable en diferents èpoques, i sempre pot ser vigent.

Tot i que, per bé que és cert que un bon logotip, ha de conseguir una permanència relativa en el temps:

"Un logotip ha de posseir una bona estructura que li permeti mantenirse en el temps l' interès visual» (Pepe Gimeno, dissenyador).

- Per un dissenyador, el més important és que la seva producció sigui intel-ligible i acceptada estèticament; reconeixible allà on sigui exposada; el més important per ell és la comnunicació (o ho hauria de ser) que no pas l'estètica del missatge:

«Dissenyar una marca és com escriure un telegrama (...) Si els destinataris del telegrama no ho entenen, ho obliden ràpid o no els sembla atractiu, haurem fet malament el nostre treball» (Manuel Estrada, dissenyador).

No entén la base de la seva feina com a finalitat artística, sinó com a element cent per cent esclau de la comunicació (en contraposició a la llibertat de realització, transmissió i concepció del poeta):

"Tot logotip ha d'estar configurat, dissenyat de tal manera que acompleixi opticament amb la seva finalitat comunicacional (subratllaria especialment l'aspecte comunicacional, donat que fer un disseny no és fer art o delectar-se en l'estètica, com molts creuen, sinó que és fer comunicació no verbal, és a dir comunicació visual).» (Yves Zimmermann, dissenyador i teòric del disseny i la publicitat).

- L'artista, esdevé un nom propi i la seva relació amb el públic és directa versus la situació de l'artista gràfic (crec que els dissenyadors mereixen aquesta distinció), la identitat del qual queda en l'anonimat i es perd en l'entramat de producció... (qui va dissenyar el logotip de ChupaChups?... Dalí!!, com canvien els papers!).

- "Les imatges visuals, al contrari de les descripcions verbals, van dirigides de manera immediata als mateixos òrgans sensorials a través dels quals reunim la informació visual respecte dels objectes que simbolitzen" (Luins).

- A les agències de publicitat hi ha la figura del Director d'Art (que estrany, que curiós, quina casualitat i quina coincidència...).

- Fins al segle XV no es dividiran clarament les dues activitats, la de l'artista i la del dissenyador gràfic.

«Plató sabia que l'escriptura duria una revolució de la percepció: que l'ull desplaçaria l'orella com a òrgan del processsament del llenguatge. És més, hi ha la llegenda que per estimular aquest desplaçament, Plató insistia que els seus alumnes estudiessin geometria abans d'entrar a la seva Acadèmia» (Neil Postman, assagista nord-americà). 


\section{BIBLIOGRAFÍA}

Balcells, Jordi i Roig, Albert, L'escriptor de Poesia. Poètica i antologia del vint. 1991.

BORDONS, Glòria, Introducció a la Poesia de Joan Brossa. Ed. 62. 1988.

-, Glòria i Subirana, Jaume. Literatura catalana contemporània. Ed. Proa. VOC. Barcelona 1999.

Brossa JoAN. Entre les coses $i$ la lectura: objectes, poemes, muntatges, instal lacions: del 25 de març al 22 de maig de 1994. Palau de la Virreina. Ajuntament de Barcelona 1994. Catàleg.

Brossa, Joan, Les sabates són més que un pedestal. Ed. Alta Fulla. Barcelona 1996.

—, Poesia visual i poemes objecte. Catàleg Joan Prats 1982-1983.

Brossa Joan, Parra Nicanor, Dir poesia, mirar poesia: març-abril 1992. Sala d'exposicions de la Universitat de València. Catàleg.

BusQueTs, Lluis, Plomes Catalanes contemporàneas. Ed. El Mall. Barcelona 1980.

CAPEll Rosa, Paraula, imatge, idea, sobre poesia visual. Tesi Doctoral. Universitat de Barcelona.

CocA, JoRd, Joan Brossa. Oblidar i Caminar. L'Esparver Llegir. Ed. La Magrana. Barcelona 1992.

FERNÁNDEZ SERRATO, Juan Carlos, Teoría y Crítica de la poesía concreto-visual en España: estudio de su significación. Tesi Doctoral. Universidad de Granada 1995.

Huerta, Ricard, Funció plàstica de les lletres. Ed. Del Bullent. València 1994.

March, Marion, Tipografia Creativa. Manuales de Diseño. Ed. Gustavo Gili. Barcelona 1989.

Munari BRUno, Diseño y comunicación visual. Ed. Gustavo Gili. GG Diseño Barcelona 1985.

MurPhy John / Rowe Michael, Cómo diseñar marcas y logotipos. Ed. Gustavo Gili. 1989, Barcelona.

Potter Norman, De, Qué es un diseñador. Ed. Paidós. Barcelona 1989.

RICARD, ANDRÉ, Hablando de diseño. Hogar del Libro, Punt de vista. Barcelona 1986

RiQuer MarTí, Història de la Literatura Catalana. Barcelona 1987.

SAlA, MÀRIUS, Logos Made in spain. Index Book 2000. Barcelona.

SATUE, ENRIC, El Diseño gráfico. Desde los orígenes hasta nuestros días. Ed. Alianza Forma. Madrid, 1995.

—, El Diseño Gráfico. Biblioteca Irina de Síntesis didácticas. 1997. 